\title{
A Multiplex PCR for Detection of Poxvirus and Papillomavirus in Cutaneous Warts from Live Birds and Museum Skins
}

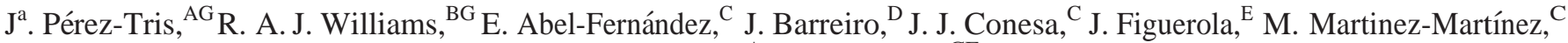 \\ A. Ramírez, ${ }^{\mathrm{A}}$ and L. Benitez ${ }^{\mathrm{CF}}$

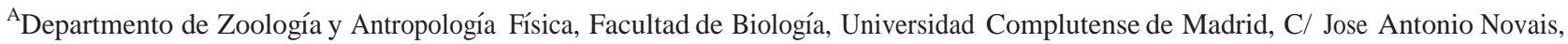 \\ 28040, Madrid, Spain \\ ${ }^{\mathrm{B}}$ Natural History Museum and Biodiversity Research Center, University of Kansas, Lawrence, KS 66045 \\ ${ }^{\mathrm{C}}$ Departmento de Microbiología III, Facultad de Biología, Universidad Complutense de Madrid, C/ Jose Antonio Novais, 28040, Madrid, Spain

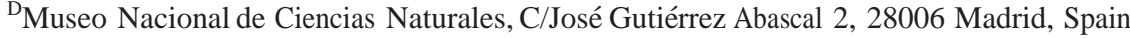 \\ ${ }^{\mathrm{E}}$ Estacion Biologica de Doñana, Consejo Superior de Investigaciones Científicas, 41013 Seville, Spain
}

\begin{abstract}
SUMMARY. Viral cutaneous lesions are frequent in some bird populations, though we are generally ignorant of the causal agent. In some instances, they represent a threat to livestock and wildlife health. We present here a multiplex PCR which detects and distinguishes infection by two such agents, avipoxviruses and papillomaviruses, in avian hosts. We assayed biopsies and superficial skin swabs from field and preserved museum skin specimens. Ninety-three percent of samples from symptomatic specimens tested positive for the presence of avipox (n 5 23) or papillomavirus (n 5 5). Sixteen and five sequences, corresponding to the P4b and L1 genes, were obtained from avipox and papillomavirus, respectively. One museum specimen, of Fringilla coelebs (chaffinch), was apparently infected with both viruses. Although papillomavirus sequences proved identical to previously published sequences, four novel avipox sequences were generated and used to build a neighbor-joining phylogenetic tree. Our tree recovered a similar topology to that of several recent authors; however, we also propose here two new minor avipox clades (B1b and B3). This multiplex PCR technique shows improved sensitivity compared to other avipox and papillomavirus assays, is able to detect a wide range of avipox and papillomavirus types (it amplifies all three avian-derived papillomavirus genera described thus far and sequences from both major avipox clades), and was even able to detect ancient viral DNA contained in museum specimens of greater than 75 years antiquity for both viruses.
\end{abstract}

RESUMEN. Método de PCR múltiple para la detección de poxvirus y papilomavirus en verrugas cutáneas de aves vivas y piezas de piel de museo.

Las lesiones cutáneas de origen viral son frecuentes en algunos grupos de aves y aunque generalmente se desconoce el agente etiológico, en algunos casos pueden representar una amenaza para la ganadería y la fauna silvestre. Se presenta aquí un método de PCR múltiple que detecta y diferencia las infecciones causadas por dos de esos agentes en aves, avipoxvirus (APV) y papilomavirus (PV). La técnica ha sido ensayada sobre biopsias y raspados cutáneos de especimenes capturados en campo y en piezas de pieles de museo. En el 93\% de las muestras de ejemplares con lesiones se detectó la presencia de avipoxvirus (n 5 23) o de papilomavirus (n 5 5). Se obtuvieron 16 secuencias de avipoxvirus y 5 secuencias de papilomavirus que corresponden a los genes P4b y L1 de avipoxivirus y papilomavirus, respectivamente. Se determinó que un espécimen de museo, correspondiente a Fringilla coelebs, (pinzón común) estaba aparentemente infectado con ambos virus. Aunque las secuencias obtenidas de papilomavirus son idénticas a las ya publicadas, se han descrito cuatro secuencias nuevas de avipoxvirus que han sido utilizadas para construir un árbol filogenético por el método neighbour-joining. El árbol generado presenta una topología similar a la descrita en trabajos ya publicados, aunque se proponen dos subclados menores de avipoxvirus (B1b y B3). Esta técnica de PCR múltiple mostró una mejora de la sensibilidad con respecto a otros ensayos para la detección de avipoxvirus y papilomavirus, siendo capaz de detectar un amplio rango de tipos en ambos grupos virales. Ha permitido la amplificación de secuencias de los tres géneros de papilomavirus aviares descritos hasta ahora y de los dos clados principales de avipoxvirus, siendo incluso capaz de detectar DNA fósil de ambos virus en especimenes de museo de más de 75 años de antigüedad.

Key words: avipoxvirus, multiplex PCR, papillomavirus

Abbreviations: APV 5 avian poxvirus; CNPV 5 Canarypox virus; cyt b 5 cytochrome b; FcPV 5 Fringilla coelebs papillomavirus; FWPV 5 Fowlpox virus; PePV 5 Psittacus erithacus papillomavirus; FIPV 5 Francolinus leucoscepus papillomavirus; PV 5 papillomavirus; SLPV 5 Starlingpox virus; TKPV 5 Turkeypox virus

Wildlife infectious diseases play a major role in regulating natural populations and their emergence may seriously threaten human, livestock, and wildlife health (5). However, natural disease dynamics, interspecies disease transmission and, in turn, disease emergence risks are unknown for the vast majority of wildlife diseases. Obviously, both our understanding of disease dynamics and our ability to anticipate the consequences of the spread and emergence of new diseases are

\footnotetext{
${ }^{\mathrm{F}}$ Corresponding author. E-mail: lbenitez@bio.ucm.es

${ }^{\mathrm{G}}$ Contributed equally.
}

greater when the screening methods are available beforehand. These methods should aim to accurately detect and identify the disease agent from a wide list of potential candidate pathogens, even if the samples are small and are poorly preserved.

Skin lesions are frequent in some bird populations, but we are still ignorant of the causal agent in most instances. Papules, nodules, or discrete masses on the feet or around the eyes and beak may be produced by viruses like poxvirus and papillomavirus or be caused by bacterial abscesses or neoplastic diseases such as epithelial tumors and soft tissue sarcomas (19). Although papillomavirus and poxvirus have been identified as viral agents for these types of lesions, so far, 
Table 1. Field samples used in this study. ${ }^{\mathrm{A}}$

\begin{tabular}{|c|c|c|c|c|c|c|c|c|}
\hline Species & Sample & Year & Lesion & Origin & $\begin{array}{l}\text { Multiplex } \\
\text { PV/APV }\end{array}$ & $\begin{array}{c}\text { Simple } \\
\text { PCR-M29 }\end{array}$ & $\begin{array}{l}\text { GenBank } \\
\text { accession }\end{array}$ & Virus strain \\
\hline Carduelis chloris & CACH & 2007 & Eyelid & Doñana, Spain & $(2) /(+)$ & $(+)$ & HM627232 & CNPV2 \\
\hline Cyanistes caeruleus & CYCA & 2007 & Legs & Canary Islands, Spain & $(2) /(+)$ & $(+)$ & HM627234 & CNPV1 \\
\hline F. coelebs & FRCO2 & 2007 & Leg & Madeira Island, Portugal & $(+) /(2)$ & NA & FN424356 & FcPV \\
\hline F. coelebs & FRCO3 & 2007 & Legs & Madeira Island, Portugal & $(+) /(2)$ & NA & FN424356 & FcPV \\
\hline F. coelebs & FRCO4 & 2007 & Legs & Madeira Island, Portugal & $(+) /(2)$ & NA & FN424356 & FcPV \\
\hline P. domesticus & PADO3 & 2009 & Leg & Chkakfa, Morocco & $(2) /(+)$ & $(+)$ & HM627220 & SLPV \\
\hline P. domesticus & PADO4 & 2009 & Leg & Chkakfa, Morocco & $(2) /(+)$ & $(+)$ & HM627220 & SLPV \\
\hline P. domesticus & PADO5 & 2009 & Leg, beak & Chkakfa, Morocco & $(2) /(+)$ & $(+)$ & HM627219 & CNPV1 \\
\hline P. domesticus & PADO6 & 2009 & None & Avila, Spain & $(2) /(2)$ & NA & - & - \\
\hline Periparus ater & PEAT & 2007 & Eyelid & Madrid, Spain & $(2) /(+)$ & $(+)$ & HM627231 & CNPV1 \\
\hline Sylvia atricapilla & SYAT1 & 2007 & Beak & Canary Islands, Spain & $(2) /(+)$ & $(+)$ & HМ627233 & CNPV1 \\
\hline
\end{tabular}

${ }^{\mathrm{A}} \mathrm{PV} 5$ papillomavirus; APV 5 avian poxvirus; CNPV1 and CNPV2 5 strains of Canarypox virus (type strain accession number AY318871); FCPV 5 Fringilla coelebs papillomavirus (type strain accession number AY057109); SLPV 5 Starlingpox virus (type strain accession number not assigned); NA 5 not assayed.

most research has focused on poxvirus to the point that the relevance of papillomavirus as a cause of avian skin lesions (either alone or in co-infection with poxvirus) remains unknown.

Avian poxviruses (APV) are enveloped, double-stranded DNA viruses included in Avipoxvirus, a highly divergent genus of Chordopoxvirinae that infects around 20 avian families worldwide (26). APV cause proliferative lesions especially around the eye, the base of the beak, and the legs and feet, although any bare patch of skin can be affected. Such lesions are firm and may be smoothsurfaced or ulcerated and covered with crust. APV infections have been diagnosed using histopathology, virus isolation, serology, and molecular methods. PCR-based molecular techniques are currently used for routine diagnosis, targeting highly conserved genes like the virion core protein $\mathrm{P} 4 \mathrm{~b}$, thymidine kinase, the late transcription factor VLTF-1, or the virion envelope protein p35 $(1,4,6,13)$.

Papillomaviruses (PV) are nonenveloped and double-stranded DNA viruses that infect the epithelia of vertebrates, causing neoplasia or persisting asymptomatically (3). To date, 120 human and 69 animal PV have been described. PVs cause smooth to irregular, cauliflowerlike masses in a variety of avian families but, so far, only three isolates have been genetically characterized (Fringilla coelebs papillomavirus [FcPV] in chaffinch; Psittacus erithacus papillomavirus [PePV] in the African grey parrot; and Francolinus leucoscepus papillomavirus [FIPV] in the yellow-necked francolin). These isolates show less than $60 \%$ of nucleotide similarity to one another (3).

The diagnosis of skin disease has traditionally relied on biopsy and histopathologic examination of skin lesions, but molecular tools are increasingly helpful in analyses of small or poorly preserved samples, not infrequent in studies of wild populations. We describe a multiplex PCR designed to detect and characterize PV and APV infections from cutaneous lesions. We show that this new method performs well using wild bird samples from both live-caught and museum voucher skin specimens. We amplify viral DNA from both sample types (including three museum skin samples prepared in the nineteenth century). Sensitivity was shown to be greater than for PCR techniques previously used in routine diagnosis of APV infection, and this is the first PCR multiplex designed to distinguish between APV and PV lesions. Indeed, we present, to the best of our knowledge for the first time, evidence of a co-infection of a bird by viruses from each group.

\section{MATERIALS AND METHODS}

Tissue samples and control plasmids. We collected biopsies and superficial skin swabs from cutaneous lesions of the legs, feet, and beaks of individuals symptomatic for viral infection and also sampled birds without lesions as negative controls. The samples were obtained from live birds captured during routine monitoring activities and from preserved skin specimens in museum collections. Swabs were preferred from live specimens with small lesions, but we also collected biopsies from larger lesions. Phosphate-buffered saline-soaked cotton-tipped swabs were rubbed against the skin or lesion surface six to 10 times and then placed in sterile tubes and stored at 280 C. In all, we analyzed 33 samples: live birds (16 individuals of 6 species; Table 1 ) and museum specimens (17 individuals of 14 species; Table 2). Museum samples were selected after examination of 1500 voucher specimens deposited in the Museo Nacional de Ciencias Naturales (Madrid, Spain) for cutaneous lesions. We included in our analysis a commercial vaccine for fowlpox (Diftosec CT, Merial Laboratories, Barcelona, Spain). Avian PV plasmid controls (pBRFPV and pBRPePV containing the complete genome of FcPV and PePV, respectively, and pUC18FIPV1/pUC18FIPV2 containing the complete genome of FlPV divided in two fragments of approximately 4 and $3.2 \mathrm{kpb}$ ) were kindly supplied by Robert Burk (Albert Einstein College of Medicine, New York, NY).

DNA extraction. We homogenized biopsies in lysis buffer containing proteinase $\mathrm{K}$ (Fermentas, Burlington, Canada) to a concentration of $500 \mathrm{mg} / \mathrm{ml}$. Homogenized samples were incubated at $60 \mathrm{C}$ for $2-3 \mathrm{hr}$. Thawed swabs were placed in lysis buffer and vortexed for 30 seconds. DNA was extracted using a standard phenol-chloroform-isoamyl alcohol technique followed by isopropanol precipitation. Nucleic acid concentration was determined using a Nanodrop ND-100 system (Nanodrop Technologies, ThermoScientific, Wilmington, DE). DNA extracts were stored at $220 \mathrm{C}$. Museum samples were repurified using centrifugal filter devices (Microcon YM-100, Millipore, Billerica, MA).

PCR primers. Prior to amplification with the multiplex PCR, DNA extracts from clinical samples were amplified with cytochrome b (cyt b) primers as a control to confirm adequate preservation of DNA (8). In order to amplify PV DNA, we designed the degenerated primers BconPVF1 (59-TYCCWAAGGTSTCTGSAAATCA-39) and BconPVR1 (59-CCRAAGCCAATATCKSACAT-39) on conserved sequences of the L1 major capsid protein gene of avian (FcPV and PePV), bovine (BPV-1), and human papillomaviruses (HPV-6, -11, -16, -18). To amplify poxvirus DNA, we used the primers M2925 and M2926, which target the P4b gene (fpv167 locus) of fowlpox virus (FWPV; Lee and Lee [10]), and designed the new primers P4b1060F (59-GATGGCTGACGAGGAACAAAT-39) and P4b1060R (59-TAGCCGGCATAAACATAACTCTTC-39), located 
Table 2. Museum skin samples used in this study. ${ }^{\mathrm{A}}$

\begin{tabular}{|c|c|c|c|c|c|c|c|c|c|c|}
\hline Species & Sample & Year & Lesion & $\begin{array}{l}\text { Sample } \\
\text { reference }\end{array}$ & Origin & $\begin{array}{l}\text { Multiplex } \\
\text { PV/APV }\end{array}$ & $\begin{array}{c}\text { Simple } \\
\text { PCR-M29 }\end{array}$ & $\begin{array}{c}\text { Simple } \\
\text { PCR-FORM }\end{array}$ & GenBank accession & Virus strain \\
\hline $\begin{array}{l}\text { Amazona } \\
\text { ochrocephala }\end{array}$ & AMOC & 1950 & Leg & 16519 & Brazil & $(2) /(+)$ & (2) & $(+)$ & - & - \\
\hline $\begin{array}{l}\text { Burhinus } \\
\text { oedicnemus }\end{array}$ & BUOE & 1980 & Leg & 8501092 & $\begin{array}{l}\text { Balearic Islands, } \\
\text { Spain }\end{array}$ & $(2) /(+)$ & $(+)$ & NA & HM627224 & TKPV \\
\hline Cyanocorax yncas & CYYN & 1923 & Leg & 13567 & Veracruz, Mexico & $(2) /(+)$ & (2) & $(+)$ & - & - \\
\hline Ducula oceanica & DUOC & Unknown & Beak & 2771 & $\begin{array}{l}\text { Carolina Islands, } \\
\text { Philippines }\end{array}$ & $(2) /(2)$ & (2) & NA & - & - \\
\hline $\begin{array}{l}\text { Emberiza } \\
\text { leucocephalos }\end{array}$ & EMLE & Unknown & Toe & 15031 & $\begin{array}{l}\text { Turkestan, } \\
\text { Kazakhstan }\end{array}$ & $(2) /(+)$ & (2) & $(+)$ & - & - \\
\hline Euphonia musica & EUMU & Unknown & Toe & 15474 & South America & $(2) /(+)$ & (2) & $(+)$ & - & - \\
\hline Fringilla coelebs & FRCO5 & Pre-1936 & Leg & 8964 & $\begin{array}{l}\text { Balearic Islands, } \\
\text { Spain }\end{array}$ & $(+) /(+)$ & $(+)$ & NA & HM627225-FN424357 & TKPV-FcPV \\
\hline F. coelebs & FICO6 & 1922 & None & 8945 & Oporto, Portugal & $(2) /(2)$ & NA & NA & - & - \\
\hline Leptotila rufaxilla & LERU & 1865 & Head & 2757 & Napo River, Peru & $(2) /(+)$ & $(+)$ & NA & HM627226 & CNPV1 \\
\hline Loxia curvirostra & LOCU & 1930 & Beak & 8926 & Guadarrama, Spain & $(2) /(+)$ & $(+)$ & NA & HM627227 & CNPV1 \\
\hline Parus afer & PAAF & Unknown & Leg & 14493 & South Africa & $(2) /(+)$ & (2) & $(+)$ & - & - \\
\hline Passer domesticus & PADO7 & 1911 & Leg & 9801 & $\begin{array}{l}\text { Tablas de } \\
\text { Daimiel, Spain }\end{array}$ & $(2) /(+)$ & $(+)$ & NA & HM627228 & CNPV2 \\
\hline Passer griseus & PAGR & 1940 & Leg & 9697 & Congo, Guinea & (2) / (+) & (2) & $(+)$ & - & - \\
\hline Pyrrhula pyrrhula & PYPY1 & 1949 & Leg & 8949 & Leon, Spain & $(2) /(+)$ & $(+)$ & NA & - & - \\
\hline $\begin{array}{l}\text { Pyrrhula pyrrhula } \\
\text { griseiventris }\end{array}$ & PYPY2 & Unknown & Leg & 9081 & Japan & $(2) /(+)$ & $(+)$ & NA & HM627229 & CNPV1 \\
\hline $\begin{array}{l}\text { Streptopelia } \\
\text { orientalis }\end{array}$ & STOR1 & 1893 & Beak & 2700 & Japan & $(2) /(2)$ & $(2)$ & NA & - & - \\
\hline S. orientalis & STOR2 & 1893 & Beak & 2701 & Japan & (2) / (+) & $(+)$ & NA & HM627230 & CNPV1 \\
\hline
\end{tabular}

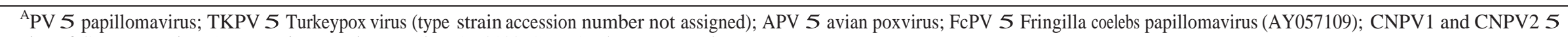
strains of Canarypox virus (type strain accession number AY318871); NA 5 not assayed. 
downstream in a conserved region between FWPV and Canarypox virus (CNPV) in the same gene. Because DNA from museum samples could have been degraded by the preservation process, we designed two additional primer pairs to amplify short fragments within the M2925M2926 region from museum samples: FORM29-1/2 (59-TGTAAAAGCCAGTCATCCTC-39 and 59-CACCGAATAAAGCTACCAATA-39) and FORM29-3/4 (59-GCCCCCGTAACAGACCTA-39 and 59-CTTTTACAGCTACACTATTACTA-39).

PCR amplifications. All amplification reactions were performed in $50 \mathrm{ml}$ of a reaction mixture containing $0.625 \mathrm{U}$ of AmpliTaq DNA polymerase (Applied Biosystems, Warrington, UK), GeneAmp II PCR buffer supplemented to a final $5.5 \mathrm{mM} \mathrm{MgCl}_{2}, 0.8 \mathrm{mM}$ concentration of each deoxynucleotide triphosphate (Fermentas), and $50 \mathrm{pmol} / \mathrm{ml}$ of each primer. Bovine serum albumin was included to a final concentration of $64 \mathrm{ng} / \mathrm{ml}$. We used from 40 to $200 \mathrm{ng}$ of cellular DNA from clinical samples and $100 \mathrm{ng}$ of control plasmids as templates. The reactions involved 45 PCR cycles (95 C for $1 \mathrm{~min}, 50 \mathrm{C}$ for $1 \mathrm{~min}$, and $72 \mathrm{C}$ for $1 \mathrm{~min}$ ) and were terminated by an extension step at $72 \mathrm{C}$ for 5 min (reactions involving primer pairs FORM29-1/2 and FORM29-3/4 were modified slightly; the annealing step was carried out at $55 \mathrm{C}$ ). All PCRs were performed on a Master Cycler Gradient (Eppendorf, Hamburg, Germany) and several DNA negative controls were included in each PCR reaction. In order to produce positive controls for multiplex PCR, PV and APV simple PCR products were inserted into vectors according to manufacturer's indications (TOPO PCR Cloning Kit; Invitrogen, Carlsbad, CA).

We visualized amplified DNA by loading $15 \mathrm{ml}$ of the PCR product in $1.5 \%$ agarose gels stained with ethidium bromide. An aliquot of positive samples was purified using a QIAquick Gel Extraction Kit (Qiagen, Hamburg, Germany) and directly sequenced on a Perkin-Elmer 2400 thermal cycler (ABI Prism Dye Terminator Cycle Sequencing Ready Reaction Kit; Applied Biosystems, Foster City, CA). The products were analyzed on an ABI Prism 3730 automated sequencer.

The nucleotide sequences obtained were analyzed with Lasergene software (DNAStar, Madison, WI). Consensus sequences were compared with known APV and PV sequences available in GenBank by using the NCBI BLAST software (http://www.ncbi.nlm.nih.gov/blast/Blast.cgi).

Phylogenetic analysis. We built a phylogenetic tree, comparing APV sequences from this study with previously published sequences, using 429 base pairs (bp) of the sequence amplified by the simple PCR-M29 set, a sequence used in previous phylogenetic analyses of APV. PV sequences were $99 \%-100 \%$ homologous to published sequences (see Results) and, therefore, were not subjected to further phylogenetic analysis.

We used MEGA 5 (23) to build a neighbor-joining phylogenetic tree based on unique APV DNA sequences found in our study or available from GenBank. We first aligned all sequences using the MUSCLE algorithm and included a homologous sequence of Molluscipoxvirus as outgroup. We selected the Tamura-Nei model of nucleotide substitution as the best of 56 possible models according to the Akaike information criterion implemented in Modeltest 3.6 (18). We used maximum likelihood as the optimality criterion and followed a heuristic search with random addition of sequences, keeping best trees only and using the nearest-neighbor-interchange algorithm for branch swapping. Support to internal branches was based on a heuristic bootstrap analysis with 1000 replicates.

\section{RESULTS}

Optimizing the multiplex PCR. Out of 33 bird samples used in our study, all but three samples (Micronesian imperial pigeon [Ducula oceanica], pine bunting [Emberiza leucocephalos], and grey-fronted dove [Leptotila rufaxila] from museum skins) tested positive for cyt b amplification and were, therefore, suitable for PCR. Nevertheless, we tested the negative samples with multiplex PCR. Only the sample from Ducula oceanica tested negative in all reactions targeting viral DNA.

Using control plasmids, we first assayed the primers BconPVF1 and BconPVR1 in a simple PCR (PCR-Bcon) on the three described types of avian PV (FcPV, PePV, and FIPV). Optimal annealing temperature was established by gradient PCR at $50 \mathrm{C}$ and an amplicon of $435 \mathrm{bp}$ was obtained from all plasmid samples. We cloned the PCR products obtained from the PePV amplification and used the resulting plasmids as positive control (pCRBcon) in subsequent analyses. We optimized an APV-specific PCR using the primers M2925 and M2926. This simple PCR (PCR-M29) was initially optimized using FWPV Diftosec CT (optimal annealing temperature was established by gradient PCR at $50 \mathrm{C}$ ), and an amplification band of the expected length (578 bp) was obtained and cloned as positive control (pCRM29).

Because we lacked a characterized panel of APV isolates, we first tested the simple PCR for PV (PCR-Bcon) and APV (PCR-M29) in each template extracted from live birds with external signs of infection (cutaneous lesions). The goal was to use positive samples for the optimization of a multiplex PCR. We preferred not to waste museum samples (which contained too little DNA) at this stage of the process. Chaffinch samples tested positive for PV infection but negative for APV, while all other field samples tested positive for APV infection and negative for $\mathrm{PV}$.

To set up a multiplex PCR reaction (M2926/27-BconPVF1/R1), temperature and concentrations of both primers were optimized using a panel of samples from live birds previously characterized by simple PCR. We assayed both artificial mixtures of samples naturally infected with both viruses and natural samples mixed with control plasmids. We were only able to obtain both bands from mixtures of the two plasmids (pCRm29 and pCRBcon) or from some bird samples mixed with APV plasmid (results not shown). Therefore, we discarded these primers for further multiplex analyses.

We designed a new APV primer pair (P4b1060F/R) to amplify 242 bp of the fpv167 gene, downstream from the M29 region. We applied the simple PCR-P4b to a field sample and cloned the product into a plasmid to get a new positive control for APV (pCRP4b). We tested this newly designed APV primer set in multiplex PCR (P4b1060F/R-BconPVF1/R1) using a panel of samples characterized by simple PCR and the previous artificial mixtures. All tests produced two bands of the expected size (435 and 242 bp, representing PV and APV, respectively). To determine the sensitivity of the multiplex PCR method, we tested 10-fold serial dilutions of an equimolar mix of the plasmids pCRP4b and pCRBcon. The lowest detectable amount was estimated to be 18 copies of each plasmid per reaction (Fig. 1).

Performance of the multiplex PCR. The newly designed multiplex PCR assay of field samples confirmed the results previously obtained by simple PCR: chaffinch samples tested positive for PV infection but negative for APV, while all other field samples tested positive for APV infection and negative for PV (Fig. 2A). The rate of success of the multiplex PCR in matching simple PCR outcomes (100\% correct in 16 field samples analyzed; Table 1) is statistically significant (Fisher exact test: P 5 0.002).

Once we determined the efficacy of our multiplex PCR for screening cutaneous lesions for viruses in live birds, we assessed its applicability for screening preserved museum skin specimens. We tested 16 samples from dried skins with proliferative lesions plus one sample from a chaffinch without visible lesions (Table 2). APV infections were detected in all dried skins except the putatively uninfected individual and two samples corresponding to Ducula oceanica and Streptopelia orientalis (oriental turtle dove; STOR1), both of them with lesions (Fig. 2B). One dried skin, believed to predate 1936, from a chaffinch in the Balearic Islands (FRCO5) produced two bands, indicating possible co-infection by PV and APV. Very faint bands were obtained from samples of yellow-crowned parrot (Amazona ocracephala), green jay (Cyanocorax yncas), Emberiza leucocephalos, Antillean euphonia (Euphonia musica), grey tit (Parus afer), and grey-headed sparrow 


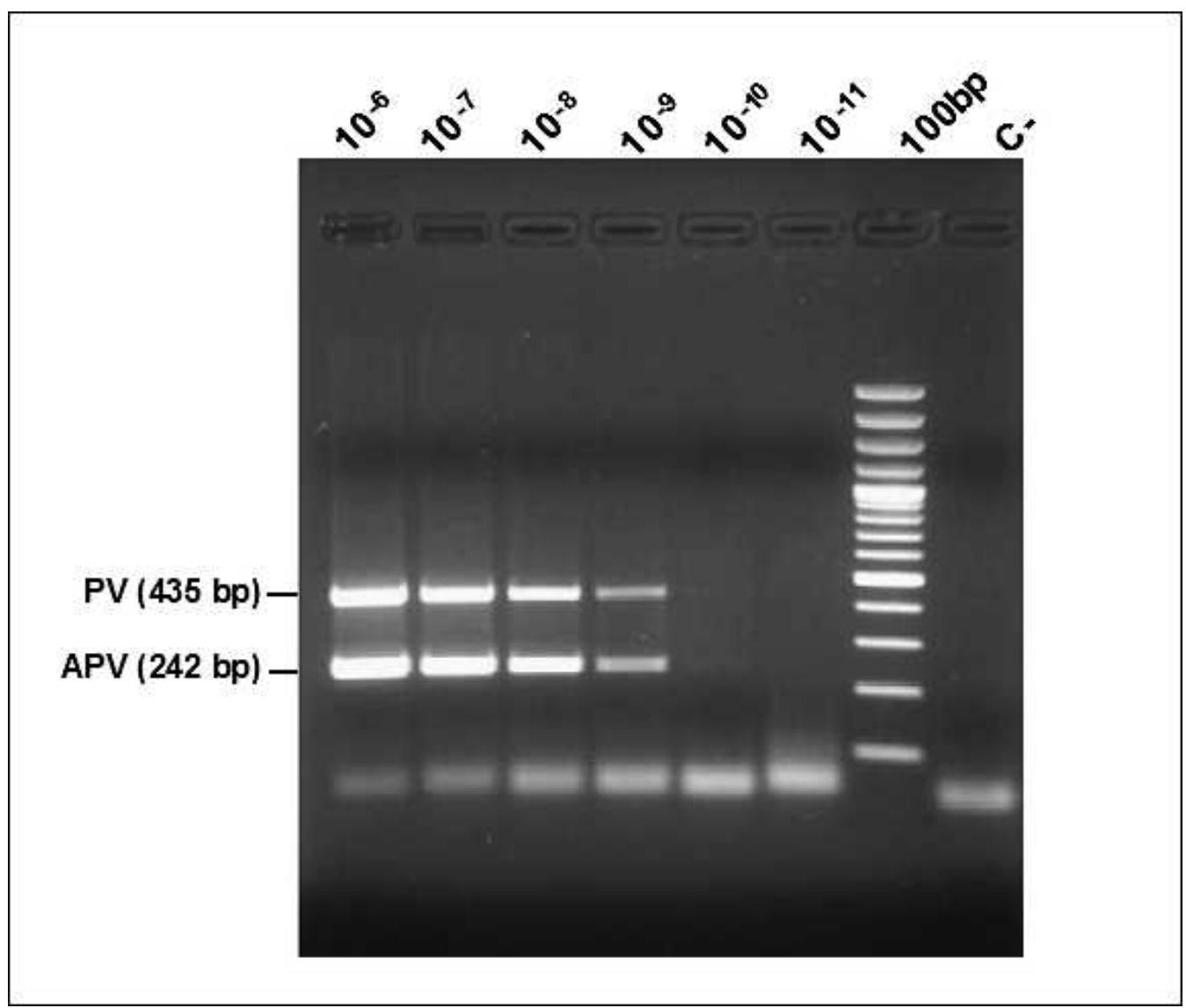

Fig. 1. Sensitivity of the multiplex PCR in detecting avian poxvirus and papillomavirus. Amplifications were performed on 10 -fold serial dilutions (from $10^{26}$ to $10^{211}$ ) of an equimolar mix of the control plasmids pCRP4b and pCRBcon. Both viruses could be detected down to the $10^{29}$ dilution, equivalent to 18 copies of each plasmid. Amplified products (15 ml) were visualised by means of $1.5 \%$ agarose gel electrophoresis. 100 bp 5 ladder; C 5 negative control without DNA; PV 5 avian papillomavirus; APV 5 avian poxvirus.

(Passer griseus), and these amplicons could not be sequenced. These samples had tested negative in the simple PCR-M29. In order to obtain sequence information from them, we designed the primers FORM291/2 and FORM29-3/4 to amplify 239- and 306-bp fragments located inside the 578 bp amplified on the M29 region. All samples corresponding to dried skins with faint results in multiplex PCR produced clear positive results when tested with both primer sets, though the resulting shorter fragments were not sequenced (Fig. 3).

Phylogenetic analyses. We compared our APV and PV isolates with published sequences. The sequences corresponding to PV showed 99\%-100\% identity to the only FCPV sequence described so far and, consequently, were not analyzed in further detail. We sequenced 16 clinical APV isolates (9 field and 7 museum specimens), and found four strains with distinct P4b sequences for the 538-bp DNA fragment analyzed, which we arbitrarily named CNPV1, CNPV2, SLPV, and TKPV. We tested these four strains together with 29 distinct APV strains for which sequences were available from GenBank. The latter were chosen to represent the diversity of APV including clades A, B, and $\mathrm{C}$ and their subclades (see [6]), plus other published sequences that fit in the phylogeny outside these clades (we named the latter after our phylogenetic analysis; Fig. 4). We aligned 429 bp of the original 538-bp sequence to fit to the shorter length of various sequences obtained from GenBank. Therefore, we conducted a phylogenetic analysis of 31 different APV strains, including the four strains found in our study. According to the maximum likelihood tree (Fig. 4), both CNPV1 and CNPV2 strains clustered together in the subclade B1, corresponding to Canarypox virus (6). The strain CNPV1 showed $100 \%$ sequence identity with the virus isolate AY318871, and we retrieved it from eight species of variable ancestry and geographic origin (Tables 1, 2). The strain CNPV2 was closely related to CNPV1 (they shared 99.8\% sequence similarity) and it was isolated from sparrows and finches in our study (Tables 1, 2). The strain SLPV clustered in the subclade B2 (Fig. 4), corresponding to Starlingpox virus (6) and showed 98\% similarity to the virus isolate AM050386. This strain was found in four house sparrows (Passer domesticus) from the same population (Table 1). Finally, the strain TKPV showed $100 \%$ sequence identity with the virus isolate DQ873809, which represents the subclade A2 (Fig. 4), corresponding to Turkeypox virus (6).

\section{DISCUSSION}

The viral agents that cause cutaneous lesions in birds have long interested researchers, primarily for their impact on poultry. Unsurprisingly, most research on these viruses has focused on FWPV. The study of APV has been boosted with the advent of PCR-based techniques for its detection, techniques that have been applied successfully in epidemiologic analyses of wild bird populations $(6,9,11,16,25,27)$.

On the other hand, the significance of PV as a disease agent in wild bird populations is not known, arguably because efficient methods to identify these viruses in samples from natural populations were lacking. Traditional investigation of avian papillomatosis has primarily relied on histologic examination of typical leg lesions, without follow-up analysis of the identity of the causative agents. Only a few 


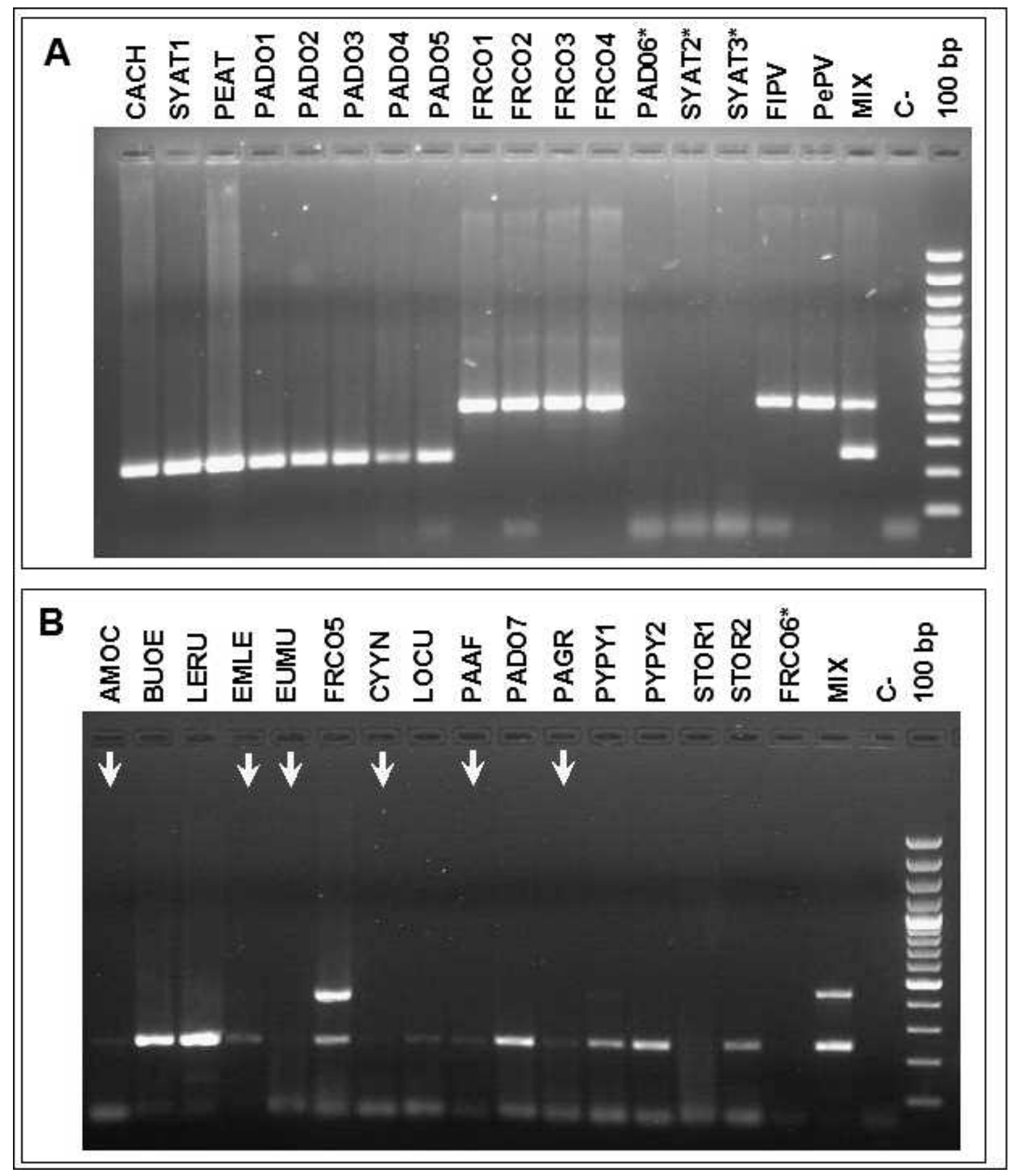

Fig. 2. Multiplex PCR for differentiation of avian poxvirus and papillomavirus in DNA samples (10 ${ }^{21}$ dilutions) from live birds (A) and museum skins (B). Sample codes follow Table 1 and 2. Samples from asymptomatic individuals are labelled with asterisks. FlPV 5 plasmid pUC18FIPV2, $10^{23}$ dilution; PePV 5 plasmid pBRPePV, $10^{24}$ dilution; MIX 5 equimolar mix of plasmids pCRP4b and pCRBcon, $10^{25}$ dilution; $\mathrm{C} 25$ negative control $\left(\mathrm{ddH}_{2} \mathrm{O}\right) ; 100$ bp 5 ladder. Several samples (arrows) produced weak results and were subsequently tested with other primers (see Fig. 3).

studies have performed molecular diagnostics using specific primers for PePV or FcPV $(20,21,24)$.

Thus, a specific, sensitive, and rapid method to detect and differentiate PV and APV infections is essential to improve our knowledge of the agents causing avian cutaneous lesions. This study presents a multiplex PCR assay to simultaneously detect APV and avian PV. The method described here uses newly designed primers that target the highly conserved APV P4b gene, previously used to diagnose FWPV infections (22) in combination with degenerated PV primers. Mixed infections of both types of viruses yield two PCR products of $435 \mathrm{bp}$ and 242 bp, corresponding to PV and APV, respectively. The multiplex PCR was evaluated using 16 field and 17 preserved museum skin specimens, all exhibiting external symptoms of viral infection (except one preserved skin specimen and three live birds), and was 


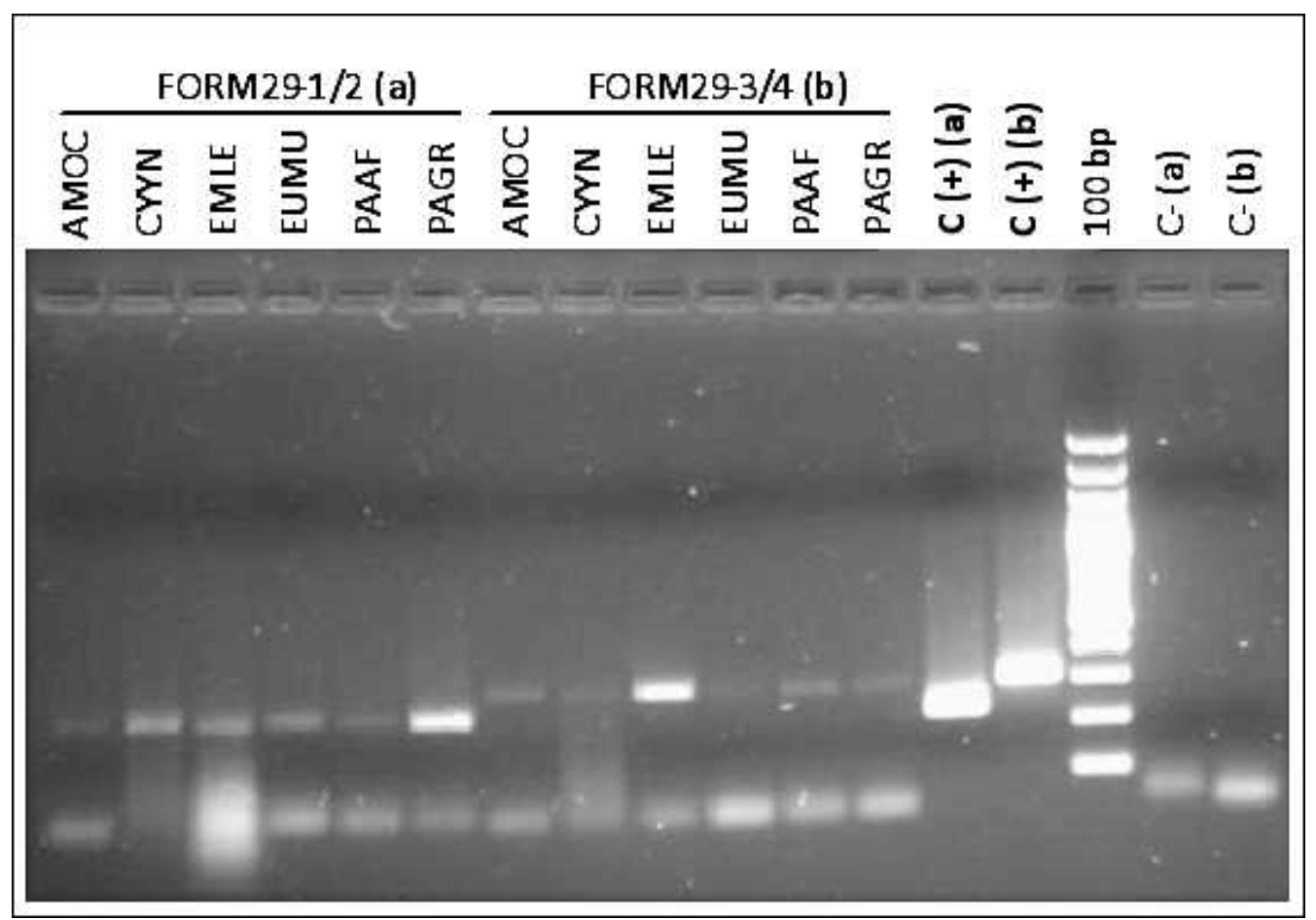

Fig. 3. Agarose gel electrophoresis of PCR-amplified products obtained from museum samples that produced weak multiplex PCR amplifications. The gel shows results obtained using primers FORM29-1/2 (lanes coded a) and FORM29-3/4 (lanes coded b). Two plasmids each containing the corresponding amplicon (a or b) have been used as positive controls (C+). 100 bp 5 ladder; C2 5 negative controls.

found to be highly sensitive for the target viruses. One or both viruses were identified from 27 of 33 samples. Negative results were obtained for four nonsymptomatic control samples, Streptopelia orientalis (STOR1), and Ducula oceanica, where beak lesions did not visually resemble APV or PV lesions. PV was amplified from all Fringilla coelebs (four live-captured birds and one museum skin specimen) tested.

Multiplex PCR clearly amplified all field samples and eight museum samples, and faint bands corresponding to APV amplification were observed from six more museum samples, though these could not be amplified by PCR-M29. Weak amplifications from museum specimens may have been caused by low viral loads in samples or, more probably, by degradation of ancient DNA which is often of poor quality in preserved specimens (17). All weakly APVpositive samples were confirmed as positive using two additional primer sets targeting shorter fragments in the same fpv167 gene, and positive reactions were obtained for 13/16 museum specimens. Thus, our multiplex PCR improves the molecular diagnosis of APV infections using samples from live birds and museum skins.

PV infection was detected in all symptomatic chaffinch specimens tested (live and preserved skins). Previous studies have identified PV by electron microscopy in this species in the Czech Republic, Great Britain, Germany, Sweden, and The Netherlands (12,14,15). This paper describes five cases of papillomatosis in chaffinches captured in two archipelagos (Baleares and Madeira). Clearly, further studies will be necessary to describe the geographic distribution of PV in chaffinches. One individual was apparently infected with both PV and $\mathrm{APV}$, to our knowledge the first reported case of co-infection of these viruses in birds. However, we did not confirm this case with additional methods (such as electron microscopy) and, therefore, simultaneous active infection by both viruses is to be considered with caution.

We identified APV infections in all symptomatic field samples (except four PV-positive Fringilla specimens) and in 14 of 16 symptomatic museum samples. The marker we used to diagnose APV infections (P4b gene) has been widely used in phylogenetic studies of APV, as it helps to differentiate among all major clades A, B, and C and the minor clades A1, A2, A3, A4, B1, and B2 (4,6,13). Minor clades B1b and B3 are proposed in this study. The APV isolated in our study clustered within the two principal clades, A and B (FWPVlike group and CNPV-like group, respectively). One important implication of this finding is that our multiplex PCR is able to detect diverse virus strains, spanning most—if not all—of the existing diversity of APV. In principle, the method should be able to amplify DNA from any APV included in the most diverse clades A and B, as well as from other clades (i.e., B3) fitting in the phylogeny between these (Fig. 4). We did not have sequences from the highly divergent clade $\mathrm{C}$ and, consequently, the ability of our method to detect viruses from this group remains untested.

We identified APV in eight genera of birds not reported before (Cyanocorax, Emberiza, Euphonia, Fringilla, Leptotila, Loxia, Pyrrhula, and Streptopelia) and in five more genera where previous cases have been described (Burhinus, Carduelis, Passer, Parus, and Periparus). Although our phylogenetic analysis is based on a single gene, our results provide new evidence that APV may sometimes be a host-generalist pathogen with a wide geographic distribution. For example, the strain CNPV1, first detected in 1948 (26), has been retrieved in avian species from a broad geographic range (central Europe, continental United States, Hawaii, Norway, and United Arab Emigrates) and with a wide phylogenetic range (various species of the orders Passeriformes and Charadriiformes) $(7,11,16)$. Accordingly, we retrieved CNPV1 from eight species of variable ancestry and geographic origin (Tables 1, 2). Likewise, the TKPV strain has been found in as divergent avian lineages as Galliformes, Sphenisciformes, and Struthioniformes (fowl, penguins, and ostriches, respectively) (4). Consistent with such a broad host range, in our study this strain was isolated from species of two orders (Charadriiformes [shorebirds and their allies] and Passeriformes [perching birds]; Table 2). From a taxonomic point of view, the 


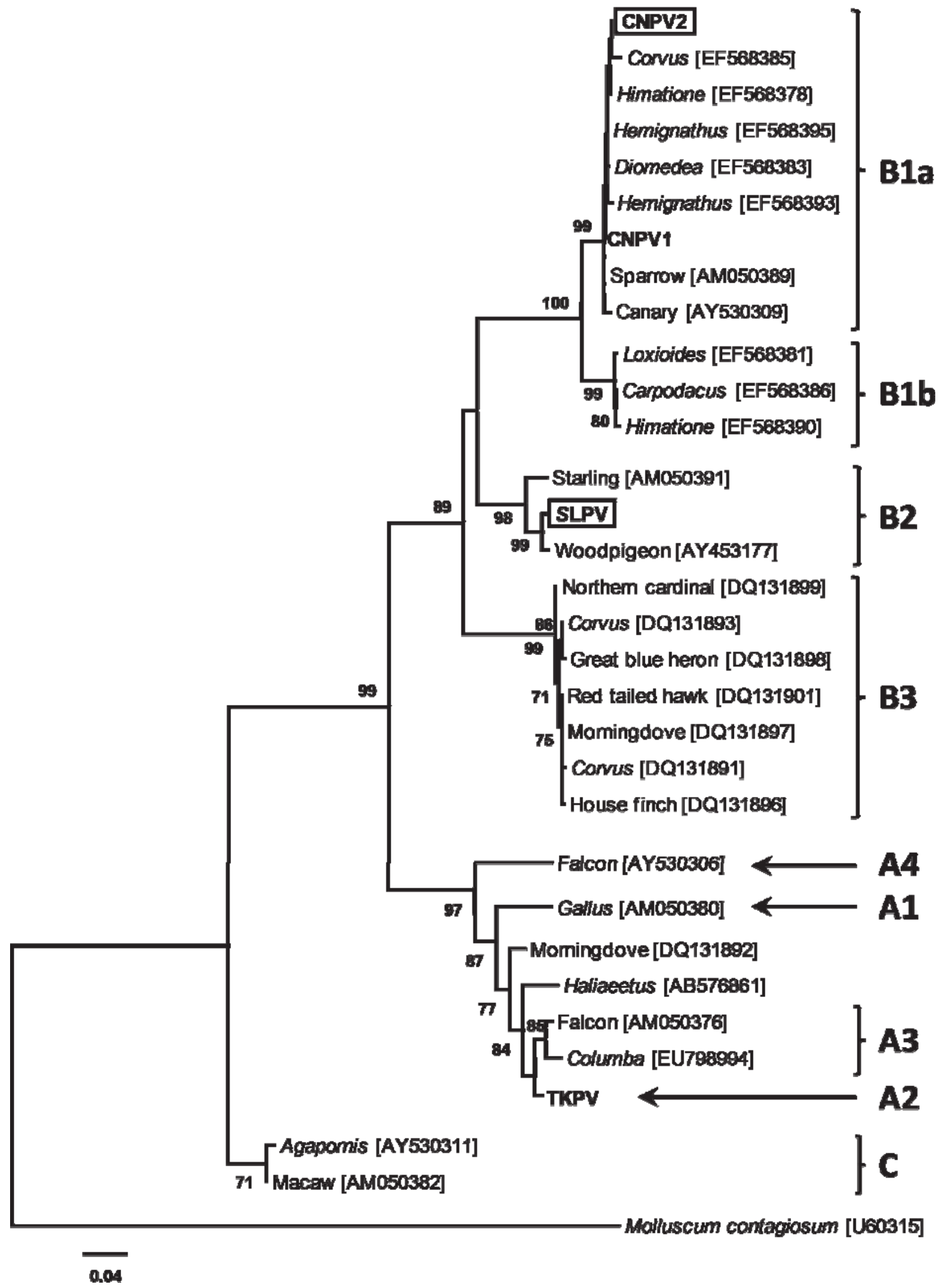

Fig. 4. Maximum likelihood tree of 31 distinct P4b avipoxvirus sequences including the four strains represented in our 16 isolates (boldfaced, squared sequences were first described in this paper). Reference sequence names indicate the name of the bird in which each sequence was first isolated (Latin or English names as recorded in GenBank) followed by GenBank accession numbers. Clades A, B, and C (and their subclades, see Jarmin et al. [6]) are labelled. Other sequences cluster together in newly named clades B3 and B1b (the latter forms a well-supported sister group to $\mathrm{B} 1$, which is labelled in the tree as B1a). Numbers near branches represent bootstrap support (1000 replicates, bootstrap values below 70 are not shown). Molluscum contagiosum virus has been used as the outgroup. 
existence of generalist virus strains undermines the argument that APVs are always host-specific and calls for a taxonomic revision of Avipoxvirus based on its phylogenetic relationships rather than on the host species from which virus strains were first isolated. However, any effort to improve the taxonomy and evolutionary relationships of avian APV should ideally consider various markers (4) because the phylogeny of single genes (such as P4b in our case) need not necessarily represent the phylogeny of virus lineages.

Our results also show that one bird population may be affected by diverse viruses. Thus, we isolated sequences clustering within subclades B1 and B2 from four house sparrows simultaneously sampled in Chkakfa (Morocco). Our results highlight the need for further research on the ecology and evolution of Avipoxvirus and call for consistency in the markers used to genetically characterise the virus strains occurring in different host species (see an example concerning avian blood parasites in Bensch et al. [2]). For example, although APV have already been found in blackcaps (Sylvia atricapilla) in Slovakia and Czech Republic (9), we could not compare that strain with the one we found in the same species in the Canary Islands (CNPV1) because the published sequences correspond to the 59 end of the thymidine kinase gene. The P4b gene is a good candidate to become the standard marker for taxonomic studies of APV, as it helps to distinguish among all APV clades so far described $(4,6)$.

This study presents a multiplex PCR assay that has great potential for the detection and identification of specific viral cutaneous infections. Positive results were obtained from all symptomatic field samples assayed, and both APV and PV could be distinguished by the size of PCR fragments and identified to strain level according to their sequences. The multiplex PCR also detected DNA of both viruses from museum skin specimens (14 out of 17), some of which had been preserved for over 100 years. One museum specimen was apparently infected with both viruses, which to our knowledge could be the first report of co-infection of PV and APV in an individual bird. The technique shows improved sensitivity compared to other PV and APV assays and is able to detect a wide range of APV and avian PV types (it amplifies all three avian-derived PV types described to date and sequences from both major avipox clades). Therefore, this multiplex PCR assay provides a powerful tool for understanding the nature of both kinds of viruses in wild populations, both in live birds and in specimens archived in museums.

\section{REFERENCES}

1. Amano, H., S. Morikawa, H. Shimizu, I. Shoji, D. Kurosawa, Y. Matsuura, T. Miyamura, and Y. Ueda. Identification of the canarypox virus thymidine kinase gene and insertion of foreign genes. Virology 256:280-290. 1999.

2. Bensch, S., O. Hellgren, and J. Perez-Tris. MalAvi: a public database of malaria parasites and related haemosporidians in avian hosts based on mitochondrial cytochrome b lineages. Mol. Ecol. Resour. 9:1353-1358. 2009.

3. Bernard, H. U., R. D. Burk, Z. G. Chen, K. van Doorslaer, H. zur Hausen, and E. M. de Villiers. Classification of papillomaviruses (PVs) based on 189 PV types and proposal of taxonomic amendments. Virology 401: 70-79. 2010.

4. Carulei, O., N. Douglass, and A. L. Williamson. Phylogenetic analysis of three genes of Penguinpox virus corresponding to Vaccinia virus G8R (VLTF-1), A3L (P4b) and H3L reveals that it is most closely related to Turkeypox virus, Ostrichpox virus and Pigeonpox virus. Virol. J. 6:e52. 2009.

5. Daszak, P., A. A. Cunningham, and A. D. Hyatt. Wildlife ecologyemerging infectious diseases of wildlife: threats to biodiversity and human health. Science 287:443-449. 2000.

6. Jarmin, S., R. Manvell, R. E. Gough, S. M. Laidlaw, and M. A. Skinner. Avipoxvirus phylogenetics: identification of a PCR length polymorphism that discriminates between the two major clades. J. Gen. Virol. 87:2191-2201. 2006.
7. Jarvi, S., D. Triglia, A. Giannoulis, M. Farias, K. Bianchi, and C. Atkinson. Diversity, origins and virulence of avipoxviruses in Hawaiian forest birds. Conserv. Genet. 9:339-348. 2008.

8. Kocher, T. D., W. K. Thomas, A. Meyer, S. V. Edwards, S. Pääbo, and F. X. Villablanca. Dynamics of mitochondrial DNA evolution in animals: amplification and sequencing with conserved primers. Proc. Natl. Acad. Sci. U. S. A. 86:6196-6200. 1989.

9. Kulich, P., E. Roubalova, L. Dubska, O. Sychra, B. Smid, and I. Literak. Avipoxvirus in blackcaps (Sylvia atricapilla). Avian Pathol. 37:101-107. 2008.

10. Lee, L. H., and K. H. Lee. Application of the polymerase chain reaction for the diagnosis of fowl poxvirus infection. J. Virol. Methods 63:113-119. 1997.

11. Lierz, M., V. Bergmann, G. Isa, C. P. Czerny, D. Lueschow, J. Mwanzia, C. Prusas, and H. H. Hafez. Avipoxvirus infection in a collection of captive stone curlews (Burhinus oedicnemus). J. Avian Med. Surg. 21:50-55. 2007.

12. Literak, I., B. Smid, and L. Valicek. Papillomatosis in chaffinches (Fringilla coelebs) in the Czech Republic and Germany. Vet. Med.-Czech 48:169-173. 2003.

13. Manarolla, G., G. Pisoni, G. Sironi, and T. Rampin. Molecular biological characterization of avian poxvirus strains isolated from different avian species. Vet. Microbiol. 140:1-8. 2010.

14. Moreno-Lopez, J., H. Ahola, A. Stenlund, A. Osterhaus, and U. Pettersson. Genome of an avian papillomavirus. J. Virol. 51:872-875. 1984.

15. Osterhaus, A., D. Ellens, and M. Horzinek. Identification and characterization of a papilloma-virus from birds (Fringillidae). Intervirology 8:351-359. 1977.

16. Palade, E. A., N. Biro, M. Dobos-Kovacs, Z. Demeter, M. Mandoki, and M. Rusvai. Poxvirus infection in Hungarian great tits (Parus major): case report. Acta Vet. Hung 56:539-546. 2008.

17. Petren, K., P. R. Grant, B. R. Grant, A. A. Clack, and N. V. Lescano. Multilocus genotypes from Charles Darwin's finches: biodiversity lost since the voyage of the Beagle. Philos. Trans. R. Soc. B. Biol. Sci. 365:1009-1018. 2010.

18. Posada, D., and K. A. Crandall. MODELTEST: testing the model of DNA substitution. Bioinformatics 14:817-818. 1998.

19. Schmidt, R. E., D. R. Reavill, and D. N. Phalen. Integument. In: Pathology of pet and aviary birds. Iowa State University Press, Ames, IA. 2003.

20. Styles, D. K., E. K. Tomaszewski, L. A. Jaeger, and D. N. Phalen. Psittacid herpesviruses associated with mucosal papillomas in neotropical parrots. Virology 325:24-35. 2005.

21. Tachezy, R., A. Rector, M. Havelkova, E. Wollants, P. Fiten, G. Opdenakker, A. B. Jenson, and J. P. Sundberg. Avian papillomaviruses: the parrot Psittacus erithacus papillomavirus (PePV) genome has a unique organization of the early protein region and is phylogenetically related to the chaffinch papillomavirus. BMC Microbiol. 2:10020-10023. 2002.

22. Tadese, T., and W. M. Reed. Detection of specific reticuloendotheliosis virus sequence and protein from REV-integrated fowlpox virus strains. J. Virol. Methods 110:99-104. 2003.

23. Tamura, K., J. Dudley, M. Nei, and S. Kumar. MEGA4: Molecular evolutionary genetics analysis (MEGA) software version 4.0. Mol. Biol. Evol. 24:1596-1599. 2007.

24. Terai, M., R. DeSalle, and R. D. Burk. Lack of canonical E6 and E7 open reading frames in bird papillomaviruses: Fringilla coelebs papillomavirus and Psittacus erithacus timneh papillomavirus. J. Virol. 76:1002010023. 2002.

25. Thiel, T., N. K. Whiteman, A. Tirape, M. I. Baquero, V. Cedeno, T. Walsh, G. J. Uzcategui, and P. G. Parker. Characterization of canarypox-like viruses infecting endemic birds in the Galapagos Islands. J. Wildl. Dis. 41:342-353. 2005.

26. Tulman, E. R., C. L. Afonso, Z. Lu, L. Zsak, G. F. Kutish, and D. L. Rock. The genome of canarypox virus. J. Virol. 78:353-366. 2004.

27. Weli, S. C., T. Traavik, M. Tryland, D. H. Coucheron, and O. Nilssen. Analysis and comparison of the 4b core protein gene of avipoxviruses from wild birds: evidence for interspecies spatial phylogenetic variation. Arch. Virol. 149:2035-2046. 2004. 